\title{
Evaluation of organic and inorganic compounds in the saliva of patients with chronic periodontal disease
}

\author{
Avaliação de compostos orgânicos e inorgânicos na saliva \\ de pacientes com doença periodontal crônica
}

\begin{abstract}
Purpose: The aim of this study was to evaluate the influence of periodontal disease on the biochemical parameters of the saliva, including salivary flow rate, $\mathrm{pH}$, total protein, alkaline phosphatase activity and urea concentration, in individuals with chronic periodontitis.

Methods: Forty subjects were allocated into two groups: twenty subjects without periodontal disease (control group) and twenty subjects with chronic periodontitis (test group). Plaque index (PI), gingival index (GI), probing depth (PD) and clinical attachment level (CAL) were obtained by a previously trained and calibrated clinical examiner. Saliva from both groups was collected for analysis of its biochemical parameters. The Student's t-test and correlation coefficient (Pearson) were used at a $5 \%$ level of significance.

Results: The results showed alterations in the alkaline phosphatase activity, urea concentration and total protein in the subjects of the test group compared to the control group $(P<0.05)$. However, there was no correlation between the clinical periodontal parameters and the salivary parameters $(P>0.05)$.

Conclusion: The results suggest that chronic periodontitis can affect the composition of the saliva and that analysis of the salivary parameters can be useful as an additional exam for the diagnosis of periodontal disease.
\end{abstract}

Key words: Dental plaque; periodontitis; saliva; alkaline phosphatase; urea

\section{Resumo}

Objetivo: $O$ objetivo deste estudo foi avaliar a influência da doença periodontal sobre os parâmetros bioquímicos da saliva, incluindo taxa de fluxo salivar, pH, proteína total, atividade de fosfatase alcalina e a concentração de uréia, em indivíduos com periodontite crônica.

Metodologia: Quarenta indivíduos foram alocados em dois grupos: vinte indivíduos sem doença periodontal (grupo controle) e vinte indivíduos com periodontite crônica (grupo teste). Índice de placa (IP), índice gengival (IG), profundidade de sondagem (PD) e nível de inserção clínica (CAL) foram obtidos anteriormente por um examinador treinado e calibrado clinicamente. Saliva de ambos os grupos foram coletadas para análise de seus parâmetros bioquímicos. O teste T de Student e coeficiente de correlação (Pearson) foram utilizados em um nível $5 \%$ de significância.

Resultados: Os resultados mostraram alterações na atividade da fosfatase alcalina, uréia e proteína total nos indivíduos do grupo teste em comparação ao grupo controle $(P<0,05)$.

No entanto, não houve correlação entre os parâmetros clínicos periodontais e os parâmetros salivares $(P>0,05)$.

Conclusão: Os resultados sugerem que a periodontite crônica pode afetar a composição da saliva e que a análise dos parâmetros salivares pode ser útil como um exame complementar para o diagnóstico da doença periodontal.

Palavras-chave: Placa dentária; periodontite; saliva; fosfatase alcalina; uréia

\author{
Arnaud Alves Bezerra Júnior a \\ Débora Pallos \\ José Roberto Cortelli b \\ Cintia Helena Coury Saraceni c \\ Celso Silva Queiroz c
}

\begin{abstract}
a Research Fellowship, Department of Dentistry, University of Taubaté, Taubaté, SP, Brazil

${ }^{b}$ Department of Dentistry, University of Taubaté, Taubaté, SP, Brazil

c Department of Dentistry, Paulista University, São Paulo, SP, Brazil
\end{abstract}

\author{
Correspondence: \\ Celso Silva Queiroz \\ Rua Dr. Bacelar, $1212-4^{\circ}$ andar \\ Vila Clementino \\ São Paulo, SP - Brasil \\ 04026-002 \\ E-mail: celsoq@yahoo.com
}

Received: February 8, 2010

Accepted: June 30, 2010

Conflict of Interest Statement: The authors state that there are no financial and personal conflicts of interest that could have inappropriately influenced their work.

Copyright: (C) 2010 Bezerra Júnior et al.; licensee EDIPUCRS. This is an Open Access article distributed under the terms of the Creative Commons AttributionNoncommercial-No Derivative Works 3.0 Unported License. 


\section{Introduction}

Chronic periodontitis is an infectious disease that results in inflammation of the protective tissues of the teeth and the progressive loss of conjunctive tissue and alveolar bone. It is the most frequently found periodontal pathology, and although its occurrence normally involves adult individuals, periodontitis can appear at any age and even affect dentitions (1).

The diagnosis of periodontal disease is accomplished through clinical periodontal parameters including plaque index, gingival index, probing depth and clinical attachment level; however, the analysis of saliva can contribute to the diagnosis and prognosis of the disease (2). The organic and inorganic composition of saliva can supply information about alterations in enzymatic activity in response to periodontal inflammation (3).

Alkaline phosphatase (ALP) is a calcium- and phosphatebinding protein and a phosphor-hydrolytic enzyme. ALP is considered to be an important indicator of bone formation and is a phenotypic marker for osteoblast cells (4). ALP was detected in the parotid, submandibular and minor salivary glands, as well as in desquamated epithelial cells, leucocytes and bacteria from dental plaque. The presence of the ALP in the saliva and in the gingival crevicular fluid is usually indicative of inflammation and/or destruction of the periodontal tissues. The level of ALP is positively correlated with the severity of the periodontal disease (5).

Among the several salivary components, urea is an organic compound that represents the final product of the human catabolism of proteins. The hydrolysis of urea by bacterial urease enzymes generates ammonia and $\mathrm{CO}_{2}$, and is considered a major pathway for alkali production in the oral cavity (6). In addition, ammonia is potentially cytotoxic for the periodontal tissues (6). Ammonia can increase the permeability of the sulcular epithelium to other antigenic and toxic substances, thereby playing a fundamental role in the initiation of gingivitis (7).

The volume of saliva in the oral cavity depends on several factors, such as stimulation, circadian rhythm, diet, age, drugs and the hydrogen $\left(\mathrm{H}^{+}\right)$ion concentration (8). Meanwhile, these factors can also be altered due to pathological conditions, such as periodontal disease (8).

The purpose of this study was to analyze the salivary parameters (flow rate, $\mathrm{pH}$, total protein, alkaline phosphatase and urea) of individuals with chronic periodontitis compared to healthy individuals. Therefore, the null hypothesis of the present study was that there are no changes of the salivary parameters in individuals with periodontal disease.

\section{Methodology}

\section{Subjects}

This study was previously submitted and approved by the Ethics Committee in Research of the University of Taubaté (protocol number: 252/08), and voluntary informed consent was signed by the participants. A pilot study was conducted in order to determine the size of sample, and five individuals with periodontal disease were compared to five individuals without periodontal disease. The data obtained from the salivary and clinical parameters were statistically analyzed (Student test, $\alpha=95 \%$ and power of 0.8 ) by the Software BioEstat 4.0. In accordance to the previous sample size calculation, forty individuals were allocated into two groups: a control group (twenty subjects without periodontal disease) and a test group (twenty subjects diagnosed with chronic periodontitis).

All patients met the following inclusion criteria: had more than 20 teeth, they had not taken antibiotics or antiinflammatory drugs in the previous 6 months, had no immunodeficiency, were healthy in general terms. Patients who were smokers or who used anxiolytics, hypnotics, antidepressants, antihistaminic, diuretics or narcotics were excluded from this study.

The volunteers in the control group showed no clinical evidence of chronic periodontitis or gingivitis, probing depth showed no bleeding (1).

Volunteers in the test group had two periodontal pockets in each quadrant with probing depth of $5 \mathrm{~mm}$ in one or more sites and presence of clinical atachment level $6 \mathrm{~mm}$ in two or more teeth (9).

\section{Evaluation of the clinical parameters}

The plaque index (PI) (10), gingival index (GI) (11), probing depth (PD) and clinical attachment level (CAL) were measured by a clinical examiner who was previously trained and calibrated. The PD was accomplished at six points per tooth.

\section{Collection and analysis of salivary parameters}

The saliva samples were collected from the patients and controls between 9:00 and 10:00 in the morning, with no oral intake of food or drink. The patients were in a seated position, with the head inclined forwards. The saliva was collected in sterilized and refrigerated tubes during 5 minutes period and immediately the saliva samples were centrifuged at $3000 \mathrm{rpm}$ for 5 minutes.

The unstimulated salivary flow was defined as the total volume of saliva produced per unit time ( $\mathrm{mL} / \mathrm{min})(12)$. The $\mathrm{pH}$ values of the saliva were immediately measured using a $\mathrm{pH}$ meter probe (PHB-Master model, Gulton, Brazil). Afterwards, $1000 \mu \mathrm{L}$ was stored at $-20^{\circ} \mathrm{C}$ until they were processed.

The protein concentration of the supernatant fluid was determined using a biuret reaction (13) that incorporates the use of Folin - Ciocalteau phenol reagent for enhanced color development (14). ALP activity was measured by colorimetric method, using monophosphate of timolftalina as the substrate (15). The saliva samples were incubated at $37^{\circ} \mathrm{C}$ for ten minutes, and the total activity of alkaline phosphatase was provided.

Urea concentration in the saliva samples was determined by Foster and Hochholzer's method (16), which use diacetylmonoxime, antipyrine (phenazone), and arsenic 
pentoxide in acid solution (sulfuric acid) like reagent. The standard solution containing $1.0 \mathrm{~g}$ urea/ $100 \mathrm{~mL}$ was used to prepare the standard curves. Each saliva sample was assayed in triplicate identical reactions.

The study variables were statistically analyzed at a $5 \%$ level of significance using the Student's t-test and Pearson correlation coefficient.

\section{Results}

The demographic data for the groups are presented in Table 1 . The mean values and standard deviations of the salivary parameters for the control and test groups are shown in Table 2. Significant differences were observed between control and test groups for all studied variables except salivary flow rate.

The correlation of the salivary parameters is shown in Table 3 . There was a positive, statistically significant correlation between the $\mathrm{pH}$ value and urea concentration, but the other correlations were not statistically significant.

The correlation between the clinical and salivary parameters showed a low correlation between the variables of the study, without statistical significance $(P>0.05)$ (Table 4$)$.

Table 1. Description of the number of individuals (n), age, frequency of male $(m)$ and female gender $(f)$, plaque index $(\mathrm{PI})$, gingival index $(\mathrm{Gl})$, probing depth (PD) (in millimeters) and clinical attachment loss (CAL) (in millimeters).

\begin{tabular}{lcc}
\hline & Test group & Control group \\
\hline $\mathrm{n}$ & 20 & 20 \\
gender & $4 \mathrm{~m} 16 \mathrm{f}$ & $8 \mathrm{~m} 12 \mathrm{f}$ \\
age & $42.27 \pm 8.07$ & $28.3 \pm 6.95$ \\
$\mathrm{PI}$ & $1.85 \pm 0.30$ & $0.40 \pm 0.49$ \\
$\mathrm{Gl}$ & $1.82 \pm 0.34$ & $0.25 \pm 0.47$ \\
$\mathrm{PD}$ & $6.44 \pm 0.98$ & $1.58 \pm 0.23$ \\
$\mathrm{CAL}$ & $3.75 \pm 1.16$ & $0.67 \pm 0.64$ \\
\hline
\end{tabular}

\section{Discussion}

The $\mathrm{pH}$ value of the saliva was higher in the group with periodontal disease. This increase can be due to the urea concentration, which is diffused from saliva to the dental plaque. The urea is metabolized quickly by bacterial urease enzymes, producing ammonia and carbonic gas and causing an elevation in the $\mathrm{pH}$ of the saliva (17).

The caries index was not evaluated in the present study. However, in a recent study by Shu et al. (18), a larger urea level was verified in the dental plaque of caries-free individuals, suggesting that enzymatic activity can increase the $\mathrm{pH}$ and decrease the development of caries.

The total protein concentration was smaller in the test group's saliva. This result can be connected to the increase in proteolysis activities that occur in periodontal pathological conditions (19).

The alkaline phosphatase (ALP) activity was larger in subjects with chronic periodontitis compared to healthy individuals. The results are in agreement with the studies of Nakamura and Slots (20), which compared the enzymatic activity in the saliva of patients with aggressive periodontitis in relation to healthy individuals. Nomura et al. (21) observed

Table 2. Averages and standard deviations of the salivary parameters: salivary flow (SF), $\mathrm{pH}$, total protein, alkaline phosphatase (ALP) and urea concentration in the control and test groups.

\begin{tabular}{lcc}
\hline & Test group & Control group \\
\hline $\mathrm{SF}(\mathrm{mL} / \mathrm{min})^{\mathrm{ns}}$ & $2.33 \pm 1.11$ & $2.88 \pm 1.07$ \\
$\mathrm{pH}^{* *}$ & $7.71 \pm 0.43$ & $6.91 \pm 0.18$ \\
Protein $(\mathrm{mg} / \mathrm{dL})^{* *}$ & $599.15 \pm 51.86$ & $618.09 \pm 17.52$ \\
ALP $(\mathrm{U} / \mathrm{L})^{* *}$ & $16.79 \pm 1.72$ & $10.63 \pm 1.48$ \\
Urea $(\mathrm{mg} / \mathrm{dL})^{* *}$ & $117.99 \pm 12.52$ & $52.67 \pm 7.27$ \\
\hline
\end{tabular}

** statistical significance $-(P<0.05)$ $\mathrm{ns}=$ not significant $-(P>0.05)$.
Table 3. Correlation among the salivary parameters: flow rate (FR), $\mathrm{pH}$, total protein, alkaline phosphatase (ALP) and urea concentration.

Table 4. Correlation among the salivary parameters: flow rate (FR), $\mathrm{pH}$, total protein, alkaline phosphatase (ALP) and urea concentration; and the clinical periodontal parameters: plaque index (PI), gingival index (Gl), probing depth (PD) and clinical attachment loss (CAL).

\begin{tabular}{|c|c|c|c|c|c|}
\hline \multirow{2}{*}{ Salivary parameters } & \multicolumn{5}{|c|}{ Salivary parameters } \\
\hline & FR & $\mathrm{PH}$ & Protein & ALP & Urea \\
\hline FR & 1.000 & $-\cdots$ & --- & ---- & ---- \\
\hline $\mathrm{pH}$ & $0.35^{\text {ns }}$ & 1.000 & --- & --- & ---- \\
\hline Protein & $-0.35^{\mathrm{ns}}$ & $-0.06^{\mathrm{ns}}$ & 1.000 & --- & $-\cdots$ \\
\hline ALP & $0.40^{\text {ns }}$ & $0.08^{\mathrm{ns}}$ & $-0.23^{\text {ns }}$ & 1.000 & ---- \\
\hline Urea & $0.23^{\mathrm{ns}}$ & $0.50^{* *}$ & -0.31 ns & $0.16^{\mathrm{ns}}$ & 1.000 \\
\hline
\end{tabular}

** statistical significance $-(P<0.05)$. $\mathrm{ns}=$ not significant $-(P>0.05)$.

\begin{tabular}{lccccc}
\hline \multirow{2}{*}{$\begin{array}{c}\text { Clinical periodontal } \\
\text { parameters }\end{array}$} & $\mathrm{FR}$ & $\mathrm{pH}$ & Protein & ALP & Urea \\
\cline { 2 - 6 } & $0.20^{\mathrm{ns}}$ & $0.15^{\mathrm{ns}}$ & $-0.40^{\mathrm{ns}}$ & $-0.23^{\mathrm{ns}}$ & $0.05^{\mathrm{ns}}$ \\
$\mathrm{PI}$ & $-0.17^{\mathrm{ns}}$ & $0.13^{\mathrm{ns}}$ & $0.45^{\mathrm{ns}}$ & $0.05^{\mathrm{ns}}$ & $-0.01^{\mathrm{ns}}$ \\
$\mathrm{GI}$ & $-0.22^{\mathrm{ns}}$ & $-0.15^{\mathrm{ns}}$ & $0.43^{\mathrm{ns}}$ & $-0.16^{\mathrm{ns}}$ & $-0.07^{\mathrm{ns}}$ \\
$\mathrm{PD}$ & $-0.46^{\mathrm{ns}}$ & $-0.007^{\mathrm{ns}}$ & $-0.13^{\mathrm{ns}}$ & $0.37^{\mathrm{ns}}$ & $-0.14^{\mathrm{ns}}$ \\
\hline $\mathrm{CAL}$ & & & & &
\end{tabular}

$\mathrm{ns}=$ not significant $(P>0.05)$. 
an increase of the ALP activity in patients with moderate and severe periodontitis.

The urea concentration in the saliva was higher in the test group, and this result corresponds with the study of Nomura et al. (21). This increase in urea is associated with bacterial urease activity, especially from gram-negative anaerobic bacteria, and the consequent formation of ammonia. Ammonia can be cytotoxic for the periodontal tissues (6). The correlation analyses between the clinical and salivary parameters were not significant. This result showed that the clinical parameters of individuals with periodontal disease as gingival bleeding, plaque, periodontal pocket does not necessarily indicate changes in $\mathrm{pH}$, total protein, alkaline phosphatase activity and concentration of urea. Perhaps, if the salivary parameters evaluated in this study were related to inflammatory agents (interleukins, growth factors) could be correlated with clinical parameters. However, there was a positive correlation between urea and $\mathrm{pH}$ levels $(\mathrm{r}=0.50$ and $\mathrm{p}=0.035$ ). This result can be explained by the catalytic activity of the urease enzyme and the consequent formation of ammonia, which can increase the $\mathrm{pH}$ of saliva (16).

The chronic periodontitis usually affects adults, and can be identified by some clinical features themselves as the presence of calculus and plaque in an amount consistent with periodontal destruction of the individual, which is of low intensity and installed a long period (1). However, additional tests such as X-rays and tomography are useful in the diagnosis of periodontal disease.

The salivary parameters can also contribute for the diagnosis of periodontal disease, since saliva is a mixture of oral fluid, its composition may reflect the composition of genvival fluid crevicular. Although this study has only assessed five salivary parameters, it is known that the presence of microorganisms existing in saliva may have a direct relationship with periodontal disease (1). There is a close association between juvenile periodontitis and Actinobacillus actinomycetemcomitans, there is evidence between periodontal disease and the development of several systemic diseases, among these, cardiovascular diseases (22), arthritis (23), pneumonia $(24,25)$ and diabetes (26).

The reason for the interest in establishing the parameters salivary how an additional tool for diagnosis of periodontal disease, is being able to distinguish a variety of components that might be useful biomarkers to detect and monitor changes in oral health. The noninvasive nature of saliva testing has been increasingly attractive to use as alternatives to blood.

\section{Conclusions}

The results suggest that chronic periodontitis can affect the composition of the saliva and that analysis of the salivary parameters can be useful as an additional exam for the diagnosis of periodontal disease.

\section{Acknowledgments}

The authors express their gratitude to Mr. José Antônio Domingos from the Laboratory of Biochemistry, UNESP, for his technical assistance.

\section{References}

1. Armitage GC. Development of a classification system for periodontal diseases and conditions. Ann Periodontol 1999;4:1-6.

2. Kaufman E, Lamster IB. The diagnostic applications of saliva: a review. Crit Rev Oral Biol Med 2002;13:197-212.

3. Todorovic T, Dozic I, Vicente-Barreto M, Ljuskovic B, Pejovic J, Marjanovic M, Knezevic M. Salivary enzymes and periodontal disease. Med Oral Patol Oral Cir Bucal 2005;133:372-8.

4. Cole DEC, Cohen MM. Mutations affecting bone-forming cells. In Hall BK (Editor): The osteoblast and osteocyte. New Jersey: Telford Press; 1990;431-87.

5. Chapple IL, Glenwright HD, Matthews JB, Thorpe GH, Lumley PJ. Site-specific alkaline phosphatase levels in gingival crevicular fluid in health and gingivitis: cross-sectional studies. J Clin Periodontol 1994;21:409-14

6. Fure S, Lingström P, Birkhed D. Effect of three months' frequent use of sugar-free chewing gum with and without urea on calculus formation. J Dent Res 1998;77:1630-7.

7. Clancy KA, Pearson S, Bowen NH, Burne RA. Characterization of recombinant, ureolytic Streptococcus mutans demonstrates an inverse relationship between dental plaque ureolytic capacity and cariogenicity. Infect Immun 2000;68:2621-9.

8. Ghezzi IN, Lange LA. Determination of variation of stimulated salivary flow rates. J Dent Res 2000;79:1874-8.

9. Machtei EE, Christersson LA, Grossi SG, Dunford R, Zambon JJ, Genco RJ. Clinical criteria for the definition of "established periodontitis". J Periodontol 1992;63:206-14.
10. Silness J, Löe H. Periodontal disease in pregnancy. II. Correlation between oral hygiene and periodontal condition. Acta Odontol Scand 1964; 22:121-35.

11. Löe H, Silness J. Periodontal disease in pregnancy prevalence and severity. Acta Odontol Scan 1963;21:533-51.

12. Dawes C. Rhythms in salivary flow rate and composition. Int J Chronobiol 1974;3:253-79.

13. Gornall AG, Bardawill CJ, David MM. Determination of serumproteins by means of the biuret reagent. J Biol Chem 1949;177:751-66.

14. Lowry OH, Rosebrough NJ, Farr AL, Randal RJ. Protein measurement with the folin-phenol reagent. J Biol Chem 1951;193:265-75.

15. Roy AV. Rapid method for determining alkaline phosphatase activity with thymolphthalein monophosphate. Clin Chem 1970:16:431-6.

16. Foster LB, Hochholzer JM. A single-reagent manual method for directly determining urea nitrogen in serum. Clin Chem 1971;17:921-5.

17. Dibdin GH, Dawes $C$. The mathematical model of influence on the $\mathrm{pH}$ of fasted dental plaque and on the changes occurring during the cariogenic challeng. Caries Res 1998;1:70-4.

18. Shu M, Morou-Bermudez E, Suárez-Pérez E, Rivera-Miranda C, Browngardt CM, Chen Y-YM et al. The relationship between dental caries status and dental plaque urease activity. Oral Microbiol Immunol 2007;22:61-6.

19. Sorsa T, Tiäderhane L, Konttinen YT, Lauhio A, Salo T, Lee HM et al. Matrix metalloproteinases: contribution to pathogenesis, diagnosis and treatment of periodontal inflammation. Ann Med 2006;38: 306-21. 
20. Nakamura M, Slots J. Salivary enzymes origin and relationship to periodontal disease. J Periodontal Res 1983;18:559-69.

21. Nomura Y, Tamaki Y, Tanaka T, Arakawa H, Tsurumoto A, Kirimura $\mathrm{K}$ et al. Screening of periodontitis with salivary enzyme tests. J Oral Sci 2006;48:177-83.

22. Kinane DF, Lowe GD. How periodontal disease may contribute to cardiovascular disease. Periodontol 2000 2000;23:121-6.

23. Mercado FB, Marshall RI, Klestov AC, Bartold PM. Relationship between rheumatoid arthritis and periodontitis. J Periodontol $2001 ; 72: 779-87$.
24. Scannapieco FA. Position paper of The American Academy of Periodontology: periodontal disease as a potential risk factor for systemic diseases. J Periodontol 1998;69:841-50.

25. Terpenning MS, Taylor GW, Lopatin DE, Kerr CK, Dominguez BL, Loesche WJ. Aspiration pneumonia: dental and oral risk factors in an order veteran population. J Am Geriatr Soc 2001; 49:557-63.

26. Miller LS, Manwell MA, Newbold D, Reding ME, Rasheed A, Blodgett J. The relationship between reduction in periodontal inflammation and diabetes control: a report of 9 cases. J Periodontol 1992;63,843-8. 